Editorial

\title{
Patient Safety in Maternity Care in Brazil: The Maternity Safety Thermometer as a Tool to Improve the Quality of Care
}

\section{Segurança do paciente em maternidades brasileiras: o termômetro de segurança da maternidade como ferramenta para melhorar a qualidade da assistência}

\author{
Heloisa de Oliveira Salgado ${ }^{1}$ João Paulo Souza ${ }^{2}$ Jane Sandall ${ }^{3}$ Carmen Simone Grilo Diniz ${ }^{1}$ \\ ${ }^{1}$ Departament of Health, Life Cicles and Society, Faculdade de Saúde \\ Pública, Universidade de São Paulo, São Paulo, São Paulo, Brasil \\ 2 Departament of Social Medicine, Faculdade de Medicina de Ribeirão \\ Preto, Universidade de São Paulo, Ribeirão Preto, São Paulo, Brasil \\ ${ }^{3}$ Division of Women's Health, School of Medicine, King's College \\ London, London, United Kingdom
}

Rev Bras Ginecol Obstet 2017;39:199-201.

Over the last few years, the topic of maternity care in Brazil has been at the heart of several debates. One of the main reasons is the overuse of interventions such as high rates of caesarean section, augmentation of labor with uterotonics and amniotomy, uterine fundal pressure during the second stage of labor (Kristeller maneuver), episiotomy and lithotomy position during childbirth, ${ }^{1}$ and mother-baby separation. ${ }^{2,3}$ In recent years, disrespect and mistreatment of women in health facilities during labor and childbirth are also frequently reported. ${ }^{4,5}$

Since the 1980s, many actions have been taken to deal with these problems, especially the high rates of caesarean section, which increases the risk of adverse outcomes in the short-term for both women and newborns, when done without medical indication. ${ }^{6}$ Overtreatment, as well as the underuse of effective and safe interventions (such as birth companion, midwifery care, ${ }^{7}$ and the clinical use of magnesium sulfate [MgSO4] for eclampsia prevention and treatment $)^{8}$ are among the main factors of maternal and neonatal complications that lead to near-miss and death, ${ }^{9}$ including hemorrhages, blood transfusion, anesthetic complications, internal organ damage, infections, thromboembolic disorder, neonatal respiratory distress, and other iatrogenic prematurity complications. ${ }^{10}$

According to Souza (2015, p. 549), ${ }^{11}$ "during the 1990 's, the increase in efforts to develop strategies that were able to reduce maternal mortality elicited a bigger understanding about the social determinants of maternal mortality, including the role of education, income, place of birth and the degree of oppression to which the woman is subject in society," lifting maternal mortality to an indicator of social development. As a result, it became one of the goals to be monitored within the Millennium Development Goals (MDG) proposed by the United Nations (UN). From the year 2000 to 2015, the MDGs helped to highlight the improvement of the indicators through the universalization of antenatal care and the institutionalization of childbirth, which led to a certain improvement in maternal mortality in Brazil, but had no effect over the ever-increasing rates of caesarean section. Those rates hit $57 \%$ in the general population, with $61 \%$ in the Southeast region in $2014,{ }^{12}$ and over $80 \%$ in the private sector $(85 \%){ }^{1}$

The latest estimates of maternal mortality ratio (MMR) place Brazil in the group of countries that have seen some improvement ${ }^{13}$ in the past 15 years. Despite that, it is key to consider that, from the obstetric transition point of view, the country is in Level $\mathrm{III},{ }^{14}$ given that the direct causes are still predominant (hemorrhage, sepsis, hypertension), and the quality of care becomes one of the main determinants of the health outcomes, especially when almost all women have access to health care.

In a context of underfinancing and overloaded health care, the quality of care in childbirth and the appropriate handling of the complications are essential to the decrease of maternal mortality, ${ }^{14}$ severe morbidity and near-miss. As a result, the use of intervention protocols that reduce maternal and neonatal morbimortality should be mandatory. ${ }^{9}$ It is also
Address for correspondence Heloisa de Oliveira Salgado, PhD, Faculdade de Saúde Pública da Universidade de São Paulo (FSP/ USP), Av. Dr. Arnaldo, 715 - São Paulo, SP, Brasil, CEP: 01246-904 (e-mail: hellosalgado@gmail.com).
DOI https://doi.org/

10.1055/s-0037-1602704.

ISSN 0100-7203.
Copyright $\odot 2017$ by Thieme Revinter Publicações Ltda, Rio de Janeiro, Brazil
License terms

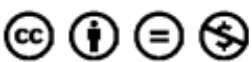


urgent the revision of the inappropriate or excessive use of interventions that may lead to iatrogenic harm in a low-risk population that, to this day, are naturalized by our society as innate to the childbirth itself ${ }^{15}$ and, in extreme situations, may lead to severe complications and/or death, ${ }^{16}$ shedding light on the need for an approach of the quaternary prevention in maternal health. ${ }^{17}$

Studies on the safety in maternal care, up until recently, were limited to audit maternal mortality, which is still an unacceptably common problem in many contexts. Most recently, the cases of severe morbidity and near-miss rightfully entered the research agenda. ${ }^{18}$ However, the great geographical variability of the negative outcomes (for instance, the rate of perineal suture, severe lacerations, hemorrhages, intensive care unit [ICU] hospitalization, and cases of post-traumatic stress disorder, among others) showed that some models of care were more associated to harm than others. The definition itself of what would be a harm is controversial, because in some countries it is expected that almost all women leave childbirth with a surgical wound (episiotomy, sutured spontaneous laceration or caesarian section), while in other contexts, this surgical injury might be considered a harm. ${ }^{19}$

In the United Kingdom (UK), England started in 2010 the Quality, Innovation, Productivity and Prevention (QIPP) national program, aiming to improve the quality of care while reducing its cost. ${ }^{20}$ The program was developed in response to concerns about avoidable harm. More than $10 \%$ of patients of the general population were harmed by care, and many times these patients and their families report a negative experience and adverse effects over their physical, mental and social well-being, and treating those iatrogenic harms has high costs. The emphasis was the decrease of four large harms already defined in previous studies that cost $£ 430$ million each to the government: pressure ulcers, falls, urinary tract infections in patients with a catheter, and venous thromboembolism. ${ }^{20}$

This innovative strategy began with the development of the concept of "harm free care" with the slogan: "it's not just counting, it's caring". ${ }^{21,22}$ This approach is based on the concept of understanding harm from the patient's perspective, allowing the verification of the presence of one or more harms in each patient, as well as harm-free care offered by the care. In collaboration with more than 160 organizations of the National Health Service (NHS), a group of experts developed an instrument called the Safety Thermometer to measure these four harms. ${ }^{20,23}$ According to these documents, "This move to take the national safety 'temperature' on four common harms across all healthcare care settings is an ambitious program that will result in an estimated 750,000 patients per quarter screened for harm"23.

Those instruments were developed to measure once a month, in real time, the "temperature of the harm" (high temperature $=$ more than one harm in an individual or an elevated number of the same harm in an institution) caused by the care. In doing so, it is possible to monitor through time, whether locally, regionally or nationally, the quality of care offered to the patients and its improvements over time. ${ }^{23}$ Within the many thermometers developed for the different areas (https://www.safetythermometer.nhs.uk/), one of them applies to the safety in maternal care: the Maternity Safety Thermometer (MST).

The MST was developed to measure maternity care in five important areas: perineal and abdominal trauma, postpartum hemorrhage, maternal infection, Apgar score of less than 7 in the 5 th minute of life, admission in a neonatal unit (for children born full-term), and women's perception of safety. $^{24}$

The MST allows maternity teams to take a temperature check on harm, and records the proportion of mothers who have experienced harm-free care, but also records the number of harms associated with maternity care. It supports improvements in patient care and patient experience, prompts immediate actions by healthcare staff, and integrates measurements for improvement into daily routines. ${ }^{24}$

The great innovation that the MST generates by being used as an instrument to measure harm caused by the maternity care is to shed light on morbidities that are frequently ignored or normalized as inevitable, for instance, rates of caesarean section and episiotomy. Moreover, measuring the frequency of hemorrhages and infections, two of the main reasons of near-miss and maternal mortality, the MST enables professionals and their teams to know their prevalence, and allows them to verify and perform over their sources, in a way to avoid hemorrhages and infections and/or treat them early. Aside from that, the MST includes neonatal outcomes as an indicator of health and safety considering mother-baby separation as a harm, an important update of scientific evidence in mother and child health. A key innovation was the measurement of women's perceptions of safety.

From the point of view of the Brazilian obstetric reality, the MST comes as an important tool, not only for monitoring the quality of the care offered to our women and newborns, but also for cultural change. First, because we have started to consider - and to name - as harm situations that have been considered for decades as inherent and unavoidable at birth: preventable caesarean section, episiotomy, mother-baby separation, and behaviors women consider disrespectful, abusive and regard as mistreatment. To treat a caesarean section or an episiotomy as a potentially avoidable harm might be the game changer for professionals and managers to start questioning their everyday use without clear medical indication.

As a result, there is the possibility of verifying and documenting with greater precision the behavior of different harms, such as the degree of laceration, the amount of blood loss, and the period in which a determined infection occurred, making it easier to plan the qualification of teams and professionals for the development of actions that aim at reducing the temperature of harms or fractions of a certain harm.

So far, there is only one Brazilian study that has used the version of this tool adapted to Brazilian Portuguese, ${ }^{25}$ having demonstrated that the MST is suitable to estimate the instant prevalence of harm in obstetric care in the state of Rio Grande do Norte. Another study ${ }^{3}$ has searched the "Birth in Brazil" 
database for the frequency of harms expected by the MST, and has identified high rates of perineal traumas, caesarean section and mother-baby separation (respectively 37.5\%, $52.6 \%$, and $69.5 \%$ ). These studies emphasize the need to start the application of the version of the tool already adapted to Brazilian Portuguese as soon as possible, beginning with few maternity wards, to correct and adjust occasional problems or difficulties with its implementation, always bearing in mind the importance of training providers for its use.

Promoting maternity care from the point of view of quaternary prevention, in other words, to avoid iatrogenic care (one that produces harms), toward a harm-free care, is an innovative approach and still a great challenge. But it might be a successful path to achieve care that not only avoids deaths and counts the number of complications, but that also effectively assists and cares about each and every one of its patients, mothers and babies.

\section{References}

1 Leal MC, Pereira AP, Domingues RM, et al. Obstetric interventions during labor and childbirth in Brazilian low-risk women. Cad Saude Publica 2014;30(Suppl 1):S1-S16

2 Moreira ELM, Gama SGN, Pereira APE, et al. Práticas de atenção hospitalar ao recém-nascido saudável no Brasil. Cad Saude Publica 2014;30(Suppl 1):S128-S139

3 Salgado HO. Cuidado materno livre de danos e prevalência de depressão pós-parto: inquérito "Nascer no Brasil", Região Sudeste, 2011 e 2012 [tese]. São Paulo: Universidade de São Paulo; 2017

4 Hotimsky SN, Aguiar JM, Venturi G. A violência institucional no parto em maternidades brasileiras. In: Venturi G, Godinho T, organizadores. Mulheres Brasileiras e gênero nos espaços público e privado - uma década de mudanças da opinião pública. São Paulo: Sesc/Fundação Perseu Abramo; 2013. p. 217-29

5 World Health Organization. The prevention and elimination of disrespect and abuse during facility-based childbirth: WHO statement. Geneva: WHO; 2014

6 World Health Organization. Caesarean section without medical indication increases risk of short-term adverse outcomes for mothers. Geneva: WHO; 2010

7 Miller S, Abalos E, Chamillard M, et al. Beyond too little, too late and too much, too soon: a pathway towards evidence-based, respectful maternity care worldwide. Lancet 2016;388(10056):2176-2192

8 Long Q Oladapo OT, Leathersich S, et al; WHO Multicountry Survey on Maternal and Newborn Health Research Network. Clinical practice patterns on the use of magnesium sulphate for treatment of pre-eclampsia and eclampsia: a multi-country survey. BJOG 2016 [Epub ahead of print]

9 Gülmezoglu AM, Lawrie TA, Hezelgrave N, et al. Interventions to reduce maternal and newborn morbidity and mortality. In: Black RE, Laxminarayan R, Temmerman M, Walker N, editors. Repro- ductive, maternal, newborn, and child health. 3rd ed. Washington (DC): World Bank; 2016. p. 115-36

10 Souza JP, Betran AP, Dumont A, et al. A global reference for caesarean section rates (C-Model): a multicountry cross-sectional study. BJOG 2016;123(03):427-436

11 Souza JP. [Maternal mortality and the new objectives of sustainable development (2016-2030)]. Rev Bras Ginecol Obstet 2015;37 (12):549-551

12 Brasil. Ministério da Saúde. DATASUS [Internet]. Informações de Saúde (Tabnet). Brasília (DF): Ministério da Saúde; 2016 [citado 2016 Dez 12]. Disponível em: http://www2.datasus.gov.br/DATASUS/index.php?area $=02$

13 WHO, UNICEF, UNFPA, World Bank Group, The United Nations Population Division. Trends in maternal mortality: 1990 to 2015. Geneva: WHO; 2015

14 Chaves SdaC, Cecatti JG, Carroli G, et al. Obstetric transition in the World Health Organization Multicountry Survey on Maternal and Newborn Health: exploring pathways for maternal mortality reduction. Rev Panam Salud Publica 2015; 37(4-5):203-210

15 Diniz CSG. Gênero, saúde materna e o paradoxo perinatal. Rev Bras Crescimento Desenvolv Hum 2009;19(02):313-326

16 Domingues RMSM, Dias MAB, Schilithz AOC, Leal MD. Factors associated with maternal near miss in childbirth and the postpartum period: findings from the birth in Brazil National Survey, 2011-2012. Reprod Health 2016;13(Suppl 3):115

17 Souza JP, Pileggi-Castro C. On labor and childbirth: the importance of quaternary prevention. Cad Saude Publica 2014;30 (Suppl 1):S1-S3

18 Say L, Souza JP, Pattinson RC; WHO working group on Maternal Mortality and Morbidity classifications. Maternal near misstowards a standard tool for monitoring quality of maternal health care. Best Pract Res Clin Obstet Gynaecol 2009;23(03): 287-296

19 Diniz SG, d'Oliveira AFPL, Lansky S. Equity and women's health services for contraception, abortion and childbirth in Brazil. Reprod Health Matters 2012;20(40):94-101

20 Power M, Fogarty M, Madsen J, et al. Learning from the design and development of the NHS Safety Thermometer. Int J Qual Health Care 2014;26(03):287-297

21 NHS [Internet]. NHS Safety Thermometer: It's not just counting ... It's caring. London: NHS; 2015 [cited 2015 Jul 1]. Available from: https://www.safetythermometer.nhs.uk/

22 Power M, Fogarty M, Harrison A, Cheema K, Bramfitt K, John N. NHS Safety Thermometer National Data Report 2014-15. London: NHS; 2016

23 Power M, Stewart K, Brotherton A. What is the NHS Safety Thermometer? Clin Risk 2012;18(05):163-169

24 NHS [Internet]. Maternity Safety Thermometer. London: NHS; 2016 [cited 2015 Jul 1]. Available from: https://www.safetythermometer.nhs.uk/index.php?option=com_content\&view=article\&id= $11 \&$ Itemid $=285$

25 Melo CR. Adaptação transcultural do Maternity Safety Thermometer para o português do Brasil [tese]. Florianópolis: Universidade Federal de Santa Catarina; 2015 